БЕЛЬКОВ Олег Алексеевич - доктор философских наук, профессор, действительный член Академии военных наук (belkovole@yandex.ru)

\title{
АПОЛОГИЯ ПОБЕДЫ: 75 ЛЕТ СПУСТЯ
}

Аннотация. Избирательный подход к истории Второй мировой и Великой Отечественной войн сегодня стал одним из основных средств сдерживания России. Фальсификация истории войны тотальна: лживо и непременно в антироссийском и русофобском духе интерпретируется все. В статье рассматриваются основные концептуальные парадигмы недоброжелателей России, раскрывается их лживость, теоретическая несостоятельность и политическая заданность. Автор обосновывает необходимость дальнейшего развертывания и организационного обеспечения противодействия фальсификации истории Великой Отечественной войны.

Ключевые слова: Великая Отечественная война, Советский Союз, Победа, творцы Победы, идеологическая борьба, фальсификация и фальсификаторы истории Великой Отечественной войны

Апология (греч. apologia) (книжн.) - устная или письменная защита, восхваление кого-, чего-либо. Словарь русского языка. В 4 т. М.: Русский язык. 1981.

T. 1. C. 42.

75 лет тому назад завершилась самая жестокая и кровопролитная битва в истории человечества. Главным творцом Победы явились Советский Союз и его Красная армия. Эта победа, по оценке В.В. Путина, навсегда останется героической вершиной в истории нашей страны ${ }^{1}$.

Во время войны и сразу после нее весь мир знал, что гитлеровский Третий рейх разгромил именно Советский Союз. Это признавали руководители всех государств антигитлеровской коалиции. «Именно русская армия, - подчеркивал У. Черчилль в послании И.В. Сталину 27 сентября 1944 г., - выпустила кишки из германской военной машины» ${ }^{2}$. «ы, - писал 8 мая 1945 г. президент США Г.С. Трумэн И.В. Сталину, - высоко ценим великолепный вклад, внесенный могучим Советским Союзом в дело цивилизации и свободы» ${ }^{3}$. Шарль де Голль в декабре 1944 г. говорил: «Французы знают, что... именно Советская Россия сыграла главную роль в их освобождении» [Великая Отечественная... 1984: 503-504].

Но практически сразу после мая 1945 г. наши союзники по антигитлеровской коалиции, прежде всего США и Великобритания, откровенно и грубо заявили о себе как о геополитическом антагонисте СССР. В фултонской речи 5 марта 1946 г. У. Черчилль открыто назвал Советский Союз причиной «международных трудностей» и обосновывал необходимость сдерживать его «под эгидой Объединенных Наций и на основе военной силы англоязычного содружества» 4 (эта речь стала сигналом к началу «холодной войны»).

Впрочем, это было новой вербализацией извечной враждебности «коллективного Запада» к России - имперской ли, советской или современной. 23 июня 1941 г. сенатор и будущий президент США Г. Трумэн заявил: «Если мы увидим,

\footnotetext{
${ }^{1}$ Выступление Президента России на военном параде 9 мая 2015 г. Доступ: http://www.kremlin.ru/ events/president/transcripts/49438 (проверено 24.05.2020).

2 Переписка председателя Совета министров СССР с президентами США и премьер-министрами Великобритании во время Великой Отечественной войны 1941-1945 г2. М.: Воскресение. 2005. С. 242.

3 Там же. С. 584.

4 Фултонская речь Уинстона Черчилля в Вестминстерском колледже. - Российское историческое общество. Доступ: https://historyrussia.org/tsekh-istorikov/archives/fultonskaya-rech-uinstona-cherchillya1946-goda.html (проверено 24.05.2020).
} 
что выигрывает Германия, то нам следует помогать России, если выигрывать будет Россия, то нам следует помогать Германии, и, таким образом, пусть они убивают как можно больше» 1 . В декабре 1941 г., когда Красная армия развернула широкомасштабные наступательные действия под Москвой, У. Черчилль заявил, что Великобритания и США «не должны принимать никакого участия» в войне СССР и Германии (за исключением обещанных поставок). А в октябре 1942 г. он утверждал, что именно Россия, а не Германия является истинным врагом Европы [Кожинов 2010: 19].

После войны одним из инструментов «сдерживания» России стал избирательный подход к истории, прежде всего к истории Второй мировой и Великой Отечественной войн. В «новом прочтении» истории, вначале антисоветском, затем «естественно» приобретшем антироссийский характер, большое место заняли спекуляции, призванные снизить уровень значения Советского Союза в Великой победе.

На ее обесценение работают политики и идеологи «коллективного Запада». В последние полтора-два десятилетия использование истории в политических целях, по словам Лаврова, «превратилось в государственное дело в целом ряде стран» ${ }^{2}$. Очень усердны в этом отношении и их отечественные подпевалы, говоря о которых С.К. Шойгу заявил, что внутри страны существует проблема «пятой колонны», действует прозападный информационный дивизион, регулярно обучаемый за рубежом ${ }^{3}$.

«Никогда бы на Западе, - считает Н.А. Нарочницкая, - не посмели так беззастенчиво менять трактовку истории, если бы первыми не стали топтать нашу Победу наши же собственные либералы. Именно они начали, и этический барьер был сорван 4 . Думается, это не совсем так. Выше уже было сказано, что наши геополитические антагонисты начали менять трактовку истории войны сразу же по ее окончании. Атаки на героические страницы и высшие символы Великой Отечественной войны со стороны отечественных либералов начались в конце $1980-x-$ начале $1990-$ х годов $^{5}$. Цель всей идеологической кампании по демонизации России двоякая. С одной стороны, лишить ее и каждого ее гражданина самоуважения (национальной гордости). С другой стороны - сформировать в мире убеждение в том, что Россия - «империя зла», извечная и страшная угроза демократическому миру, и обосновать объективную необходимость ее «переформатирования», а также внедрить в общественное сознание идею, что при «при правильной организации дела» возможна и военная победа над Россией.

Клевета на нашу Победу достигла таких масштабов, что нельзя быть по отношению к этому толерантными. Как написал историк Юрий Жуков,

1 Сахаров Н.А. Трумэн. - Большая российская энциклопедия. М. 2016. Т. 32. С. 460.

2 Лавров С.В. Трагедия Второй мировой: кто виноват? - Российская газета. 2009. 1 сен. Доступ: http://peacekeeper.ru/ru/?action=view\&id=9697\&module=news (проверено 24.05.2020).

3 Шойгу: Внутри России действует НАТОвская «пятая колонна». Доступ: https://newsland.com/ community/7451/content/shoigu-vnutri-rossii-deistvuet-natovskaia-piataia-kolonna/7071337 (проверено 24.05.2020).

4 «Первыми топтать наш жертвенный подвиг начали наши же ниспровергатели». Беседа с историком и политиком Наталией Нарочницкой. - Столетие: информационно-аналитическое издание Фонда исторической перспективы. Доступ: http://www.stoletie.ru/obschestvo/pervymi_toptat_nash_ zhertvennyj_podvig_nachali_nashi_zhe_nisprovergateli_754.htm (проверено 24.05.2020).

5 Лутовинов В.И. Великая Победа в зеркале особенностей и проблем современной России. Доступ: http://isgi.ru/article/lutovinov-vi-velikaya-pobeda-v-zerkale-osobennostey-i-problem-sovremennoy-rossii (проверено 24.05.2020); Литвиненко В.В. Черные мифы о Великой Победе. - Советская Россия. 2020. 28 янв. 
«нашу Победу пора спасать» 1 . На это нацеливает и предлагаемая поправка к Конституции: «Умаление значения подвига народа при защите Отечества не допускается».

Именно в этом смысл настоящей статьи. Остановимся на измышлениях концептуального характера.

Война есть политическое действо средствами и методами военного насилия. Соответственно, победа в ней имеет двоякое содержание. Ее политический смысл заключается в восстановлении или сохранении суверенитета и территориальной целостности собственной геополитической субъектности (суверенитета и территориальной целостности страны) и ликвидации или изменении геополитической субъектности противника. Агрессия Германии, заявил И.В. Сталин в выступлении 3 июля 1941 г., поставила вопрос «о жизни и смерти Советского государства, о жизни и смерти народов СССР». Условием положительного решения этого вопроса была военная победа - полный разгром агрессора и его капитуляция.

Победы не было бы, если бы Красная армия прекратила военные действия по выходе на государственную границу страны, за что задним числом ратуют некоторые историки. Ведь это означало бы, что агрессор не разбит, у него сохранилась, хотя и значительно ослабленная, военная мощь и, следовательно, возможность реванша. К тому же это было бы предательством по отношению к союзникам, в июне 1944 г. открывшим второй фронт. Красный флаг, водруженный над рейхстагом 1 мая 1945 г., и маршал Г.К. Жуков, принявший безоговорочную капитуляцию Германии, стали неоспоримыми символами того, что Великую Отечественную войну СССР завершил политическим и военным триумфом.

Между тем многие недруги России пересматривают смысл и содержание Победы в Великой Отечественной войне. Одни заявляют, что «Сталин проиграл Вторую мировую», другие задаются вопросом, не была ли та победа «последним приливом сил умирающего», третьи сожалеют, что не Германия победила в 1945 , еще лучше - в 1941 г.; четвертые вещают, будто козыряние России участием во Второй мировой давно наскучило, а декларации о полной победе над фашизмом стали забавными; пятые обвиняют ветеранов в том, что у них не хватило ни интеллекта, ни мужества выступить против уже отжившей социальной системы России; шестые чествование Победы и победителей называют глумливым словом «победобесие» ${ }^{2}$ и т.д. [Винтер 2012: 4; Солонин 2011: 455; Попов 2005].

Творцы и популяризаторы черных мифов о Великой Победе ныне доминируют в российском информационном пространстве, о чем свидетельствует множество книг фальсификаторов на полках книжных магазинов. Только за последние 3 года книги, очерняющие и принижающие подвиг народа в Великой Отечественной войне, опубликовали Марк Солонин (11 книг, из них 6 - в 2019 г.); Борис Соколов - 8 книг; Владимир Бешанов - 5 книг. Кроме того, в этот период опубликованы книги Владимира Резуна, Андрея Зубова и др. ${ }^{3}$ Измышления ненавистников Победы способны переформатировать истори-

\footnotetext{
${ }^{1}$ Историк Юрий Жуков: «Нашу Победу пора спасать. Ложь должна быть уголовно наказуемой». Доступ: http://pravoclavie.info/1986-istorik-yuriy-zhukov-nashu-pobedu-pora-spasat-lozh-fdolzhna-bytugolovno-nakazuemoy.html (проверено 24.05.2020).

2 Минкин. Чья победа? - Московский комсомолец. 2005. 22 июня; Особенности национальных пропагандистов. Александр Невзоров. Доступ: https://zen.yandex.ru/media/id/5daadf4b74f1bc00b0479645/ osobennosti-nacionalnyh-propagandistov--3-aleksandr-nevzorov-5ddcf1b4e488001108118129 (проверено 24.05.2020).

3 Литвиненко В.В. Черные мифы о Великой Победе. - Советская Россия. 2020. 28 янв. № 8.
} 
ческую память населения, прежде всего молодежи. Они не должны оставаться безответными. Попробую раскрыть ущербность названных выше идеологем.

«А вдруг было бы лучше, если бы не Сталин Гитлера победил, а Гитлер Сталина? <...> Погибла бы не Россия, а режим. Сталинизм... Мы освободили Германию. Может, лучше бы освободили нас?» - так написал А. Минкин. Другие рассуждают о том, что если бы Россия не сопротивлялась, то мы «сейчас бы пили баварское пиво». Подобная пораженческая позиция не является откровением современных переписчиков истории. Почти 250 лет тому назад ее сформулировал отрицательный герой романа Ф.М. Достоевского «Братья Карамазовы» Смердяков: «Я всю Россию ненавижу... В двенадцатом году было на Россию великое нашествие императора Наполеона французского первого, и хорошо, кабы нас тогда покорили эти самые французы, умная нация покорила бы весьма глупую-с и присоединила к себе. Совсем даже были бы другие порядки».

Однако, во-первых, причины войны, навязанной Советскому Союзу, лежали не только и даже не столько в идеологических различиях стран, сколько в богатстве сырьевыми ресурсами, мощи и цивилизационном своеобразии России, являющейся по некоторым вопросам антагонистом западной цивилизации. Рассуждения о том, что это была война двух тиранов, двух тоталитарных режимов, что главной целью Германии в ней было уничтожение сталинского режима, свидетельствуют либо об интеллектуальной убогости, либо идеологической враждебности. Целью было уничтожение не Сталина и не сталинского режима, а России как государства и славян как национальной группы.

Идеологи «нового видения» истории Великой Отечественной войны стремятся упразднить, вытравить из сознания людей само это понятие, ставя вместо него «нацистско-советская война». Такое ее определение проникло даже в учебники [История России... 2009]. При этом «советскость» рассматривается как характеристика не геополитического субъекта, а режима в нем, и делается вывод, что в войне двух тираний победа любой из них означает поражение страны и народа.

Семантическая бессмыслица словосочетания «советско-нацистская война» заключается в том, что абстрактный самодостаточный политический режим вне территории (страны) и без людей (народа) невозможен в принципе и, по определению, не способен вести войну. Но это не терминологический спор, а смысловое столкновение, имеющее политическое содержание. Если война представляет собой столкновение двух тираний, то победа любой из них означает поражение страны и народа. Из этой логики вытекает, что коль скоро воюет режим, представляющий собой абсолютное зло, то само зло и его служители должны быть наказаны. «Презрение потомков, - так написал А. Подрабинек, - самое малое из того, что заслужили строители и защитники советского режима» ${ }^{1}$.

Во-вторых, мягко говоря, очень спорно, было бы Советскому Союзу лучше, если бы он, подобно Дании, отказался от сопротивления. Что бы случилось, если бы Третий рейх одержал победу над СССР? Какая судьба ждала советское население? Ответ на этот вопрос дал Гитлер, указав, что предстоящая война будет войной на уничтожение, и план «Ост», предусматривавший выселение $85 \%$ коренного советского населения в Западную Сибирь, Северный Кавказ и Южную Америку. Для общего сокращения населения внедрялась программа «Глод» 2 .

1 Подрабинек А. Как антисоветчик антисоветчикам... Доступ: https://introvertum.com/kakantisovetchik-antisovetchikam-statya-aleksandra-podrabineka/ (проверено 24.05.2020).

2 «Пили бы сейчас баварское...» Что Гитлер планировал сделать с СССР после победы? Доступ: https://zen.yandex.ru/media/history_of_wars/pili-by-seichas-bavarskoe-chto-gitler-planiroval-sdelat-s-sssrposle-pobedy-5cc36191589ccd00b228707f (проверено 24.05.2020). 
Поэтому Победа - безоговорочное и великое благо. Ценой подвига, страданий и жертвенной смерти многих миллионов людей она предотвратила уничтожение страны и народа, прекращение их истории. Любая альтернатива ей являлась гибельной для страны и народа. Ведь в той войне, как отметил В.В. Путин, «речь шла не только о существовании нашей страны, речь шла о существовании самого нашего народа как этноса» 1 . Так что в случае военного поражения Советского Союза на его территории баварское пиво пили бы, но отнюдь не русские.

Военный разгром и политическое уничтожение фашизма оказали глубочайшее воздействие на ход мирового развития. Защитив себя, Советский Союз спас мир от фашистского мракобесия, преградил путь германскому фашизму к мировому господству, ликвидировал опасность распространения агрессии на другие страны и континенты. Нюрнбергский процесс, ставший одним из важных итогов войны, сыграл особенную роль в освобождении мира от «коричневой чумы». Он стал правовым, моральным и политическим разоблачением фашизма, его планов завоевания мирового господства и уничтожения целых государств и народов.

Победа восстановила попранный фашистами суверенитет европейских государств. Сейчас в странах Балтии, Польше, некоторых других государствах муссируется идея, будто разгром фашистского захватчика не принес их народам свободу, а лишь заменил германскую оккупацию на советскую. Так, МИД Болгарии сделал официальное заявление, что вход Красной армии в Болгарию в 1944 г. не был освобождением от немецко-фашистской оккупации, но стал началом навязывания болгарам чуждых им советских порядков ${ }^{2}$ Как заявила президент Эстонии К. Кальюлайд, Вторая мировая война для страны закончилась всего 25 лет назад, когда в 1994 г. Эстонию покинули «последние вагоны с техникой оккупационных войск», имея в виду вывод подразделений бывшей советской, а на тот момент - российской армии ${ }^{3}$.

Но так ли это? Захваченные Германией территории были превращены в бессубъектные рейхскомиссариаты и протектораты, последовательно освобождаемые от местного населения. Не будь советской Победы, все эти лимитрофы прекратили бы свою национальную историю вообще. По нацистскому плану, они должны были едва читать на немецком языке географические указатели в «Ингерманландии».

В результате же так называемой советской оккупации одни, как, например, Польша или Литва, не только восстановили свой государственный суверенитет, но обрели новые территории; Чехословакия (ныне - Чехия) вновь распространила свой суверенитет на Судетскую область. Другие - те же Эстония, Латвия - из захудалых аграрных задворок Европы превратились в индустриально развитые государства. И верхом цинизма является требование, например, Латвии, к России компенсировать издержки от оккупации, не ставя вопрос об оплате советских вложений (за счет России) в ее экономическое, социальное и культурное развитие.

Формой дискредитации Победы является замалчивание или даже отрицание решающего вклада СССР в разгром армий фашистского блока. Так, некоторые авторы разделяют Вторую мировую и Великую Отечественную войны, умаляя

\footnotetext{
1 Торжественный прием по случаю Дня Победы. 9 мая 2017 г. Доступ: http://kremlin.ru/events/ president/news/54469 (проверено 01.06.2020)

2 https://zen.yandex.ru/media/history_russian/pretenzii-bolgarii-k-rossii-ili-chem-bolgary-obiazanyrossiiskoi-imperii-5ddb6a99f2c2912a0dd2a83 d? \&dbr=1 (проверено 29.11.2019).

3 https://aif.ru/politics/world/okkupaciya_do_1994_goda_prezident_estonii_vydumala_novuyu_istoriyu_ voyny (проверено 25.05.2020).
} 
значение второй. Резун, выступая против вычленения Великой Отечественной войны из Второй мировой войны, заявляет: «Великая Отечественная война - это пропаганда», и добавляет: «Была Вторая мировая война, в которой Советский Союз участвовал с самого первого дня как агрессор и завершил Вторую мировую как агрессор» ${ }^{1}$. В поздравительном сообщении, опубликованном администрацией США 9 мая 2020 г., сказано, что 8 мая 1945 г. Америка и Великобритания «одержали победу над нацистами... Дух Америки всегда победит». Советский Союз в публикации не упоминается². Бывший министр иностранных дел Украины Павел Климкин заявил, что у России нет права отмечать 9 мая, и День Победы над нацизмом ей не принадлежит. Москва незаконно приватизировала Победу ${ }^{3}$.

Однако во время войны мир считал иначе. Приведу несколько цифр в подтверждение того, что Советский Союз внес решающий вклад в разгром фашистской военной машины. На протяжении почти 4 лет советско-германский фронт приковывал к себе основную массу сил и средств фашистской Германии и ее союзников. Против советских войск одновременно действовало от 190 до 270 наиболее боеспособных дивизий фашистского блока - более $3 / 4$ их общего числа (англо-американским войскам в Северной Африке в 1941-1943 гг. противостояли от 9 до 20 дивизий, в Италии - от 7 до 26, в Западной Европе после июня 1944 г. - от 56 до 75 дивизий). На советско-германском фронте были разгромлены и пленены 607 дивизий противника (западные союзники разгромили и пленили 176 дивизий). За время войны советскими войсками уничтожены и захвачены более $75 \%$ всего оружия и военной техники врага 4 . И после открытия второго фронта потери немецко-фашистской стороны на советско-германском фронте были в 4 раза больше, чем на западном и адриатическом вместе взятых 5 .

Если бы было иначе, послевоенный мир стал бы совсем другим. Два факта говорят об этом. Факт первый. По указанию У. Черчилля, к 22 мая в исключительной секретности был разработан план операции «Немыслимое». Согласно ему, наши союзники совместно с 10-12 нерасформированными и неразоруженными дивизиями вермахта должны были 1 июля развернуть военные действия против Красной армии. План остался на бумаге. До войны дело тогда не дошло $^{6}$. Факт второй. В фултонской речи 5 марта 1946 г. У. Черчилль открыто назвал Советский Союз причиной «международных трудностей» и обосновывал необходимость сдерживать его «под эгидой Объединенных Наций и на основе военной силы англоязычного содружества».

Впрочем, и в наши дни есть головы, трезво оценивающие ситуацию. Глава МИДа Польши Я. Чапутович заявил, что между Польшей и Россией нет расхождений в трактовке победы над фашизмом: СССР сделал решающие и главные шаги для разгрома гитлеровской Германии ${ }^{7}$.

Много спекуляций на тему цены Победы. С одной стороны, наши недруги как бы соревнуются, кто большее число жертв назовет, «уличив» полити-

1 Суворов В. Никакой Великой Отечественной войны не было. Доступ: https://awoxx-2207. livejournal.com/53954.html (проверено 24.05.2020).

2 https://lenta.ru/news/2020/05/09/dom/ (проверено 24.05.2020).

3 https://zen.yandex.ru/media/oboz/klimkin-zaiavil-chto-rossii-nelzia-dat-prisvoit-pobedu-vo-vtoroimirovoi-5eb8e4468a06122feefeecdc (проверено 26.05.2020).

4 Военная энциклопедия. В 8 т. 1994. М.: Воениздат. Т. 2. С. 314.

5 Скороход Ю. Что мы знаем и чего мы не знаем о Великой Отечественной войне. Доступ: https:// dom-knig.com/read_218617 (проверено 25.05.2020).

6 Операция «Немыслимое». Доклад Штаба объединенного планирования. Доступ: http://www. coldwar.ru/bases/operation-unthinkable.php (проверено 24.05.2020).

7 В МИД Польши признали ведущую роль СССР в победе над фашистской Германией. Доступ: https://www.gazeta.ru/army/news/2020/03/11/14145883.shtml (проверено 24.05.2020). 
ческое руководство и военное командование в бесчеловечности ведения войны. Подтасовывая факты в своих интересах, фальсификаторы истории Великой Отечественной войны говорят, что цена победы СССР была столь велика, что эту победу впору считать пирровой ${ }^{1}$.

Но, во-первых, цена войны (число погибших и умерших во время и вследствие войны) и цена Победы (число безвозвратных потерь комбатантов) - разные вещи. Первая названа официально - 27 млн чел. Из них 16 млн умерли вне боевых действий. Во-вторых, боевые потери наши и противника вполне сопоставимы (соотношение $1,3: 1,0)$. Превышение советских потерь объясняется в т.ч. гибелью военнопленных.

М. Солонин задается вопросом: «Не надорвались ли духовные силы народа на сверхчеловеческом напряжении тех четырех лет?» [Солонин 2011: 455]. Пассаж этот провокационен: автор в форме вопросительного высказывания вбивает в голову читателя уничижительную оценку Победы. Но жизнь ответила: война не только не подорвала, но прояснила и возвысила духовные силы народа. Из войны Советский Союз в военном отношении вышел более могущественным, чем был до нее, и Победа сделала невозможной еще одну войну. В подтверждение можно напомнить, что операция «Немыслимое» осталась только планом в силу того, что Объединенный комитет начальников штабов установил: «Если начнется война, достигнуть быстрого ограниченного успеха будет вне наших возможностей, и мы окажемся втянутыми в длительную войну против превосходящих сил» ${ }^{2}$.

Немало спекуляций по поводу того, кто был творцом Победы. Одна из самых расхожих - победа достигнута не благодаря, а вопреки Сталину, советскому руководству и в какой-то мере военному командованию. Но это утверждение является абсолютной нелепицей. Вооруженные люди без командира - это просто толпа, не способная вести систематические и согласованные военные действия. Государственный комитет обороны, Ставка Верховного главнокомандования и лично Сталин и были тем «командиром», что вел народ и армию к Победе.

Своеобразным признанием решающей роли государственного руководства, лично Сталина в организации отпора агрессору являются слова их принципиальных противников. Так, Г.Х. Попов в насквозь антисталинской работе вынужден признать: «Звездный час Сталина - не парад 1945-го. И даже не парад 1941-го. Это тот час, когда русские люди признали в нем лидера русского народа в смертельной схватке, в Отечественной войне за спасение Родины, за спасение русской нации» [Попов 2005].

Войну вел и в ней победил советский народ. Согласно указу Президиума Верховного Совета СССР от 8 мая 1945 г., 9 мая был установлен как «Праздник победы (с маленькой буквы) Красной Армии и советского народа над нацистской Германией в Великой Отечественной войне 1941-1945 годов». Да и ныне День воинской славы России 9 мая дословно называется День Победы советского народа в Великой Отечественной войне 1941-1945 годов». Эту мысль В.В. Путин дважды повторил в выступлении на церемонии возложения цветов к Могиле Неизвестного Солдата 9 мая 2020 г.: «Мы отдаем дань бесконечного признания великому, жертвенному подвигу советского народа, и этот мир отстоял, сберег советский солдат» ${ }^{3}$. В этом контексте советский народ - не гео-

\footnotetext{
1 Пиррова победа - победа, доставшаяся слишком высокой ценой; победа, равносильная поражению. По словам древнегреческого историка Плутарха, царь Эпира Пирр после своей победы над римлянами под Аускулумом в 279 до н. э. воскликнул: «Еще одна такая победа, и мы погибли».

2 Операция «Немыслимое». Доклад Штаба объединенного планирования.

3 75-летие Победы. Доступ: http://kremlin.ru/events/president/news/63329 (проверено 24.05.2020).
} 
графическая характеристика, а социально-политическая категория, общность, сущность и черты которой определял государственный и общественный строй.

Заявив о себе как о правопреемнике Союза ССР и, следовательно, Победы советского народа в Великой Отечественной войне, Российская Федерация взяла на себя ответственность за сохранение правды о ней. Но вот что интересно. В.В. Путин сказал, что предпринимаются попытки «украсть у нас победу», указав на необходимость активно этому противостоять. В ответ в Интернете появилась масса возмущенных откликов типа: «путинская РФ не имеет к Победе наших отцов никакого отношения» ${ }^{1}$. Согласиться с такой реакцией невозможно. «Путинская Россия» в человеческом измерении - это, к сожалению, уже немногочисленные ветераны, а также родные погибших и ушедших из жизни после войны защитников Отечества, их дети и внуки. Они не имеют отношения к Победе? Отторжение современной России от Победы это антиисторичный вызов здравому смыслу. Скорее наоборот, упрекать государство следует не в том, что оно признает за Россией наследника победителей, а в том, что умалчивает источники и факторы Победы и в дни торжеств скрывает ее символы.

\section{Список литературы}

Великая Отечественная война Советского Союза. 1941-1945: Краткая история. 1984. М.: Воениздат. 560 с.

Винтер Д. 2012. Виктор Суворов прав! Сталин проиграл Вторую мировую войну. Запретная правда о Победе. М.: Яуза-Пресс. 286 с.

История России. ХХ век: 1939-2007 (под ред. А.Б. Зубова). 2009. М.: Астрель; ACT. 829 c.

Кожинов В.В. 2010. Великая война России. Почему непобедим русский народ? М.: Эксмо. 540 с.

Попов Г.Х. 2005. Три войны Сталина. М.: Агентство «КРПА Олимп». 189 с. Солонин М. 2011. 22 июня: Анатомия катастрофы. М.: Яуза; Эксмо. 477 с.

\section{APOLOGY OF VICTORY: 75 YEARS LATER}

Abstract. The selective approach to the history of World War II and the Great Patriotic War has become one of the main means of containment of Russia today. The falsification of the history of war is total: everything is interpreted in a false and indispensable manner and the anti-Russian and Russophobian spirit. The article discusses the basic conceptual paradigms of the detractors of Russia and reveals their deceit, theoretical insolvency and political assignment. The author substantiates the necessity of further deployment and organizational support to counter the falsification of the history of the Great Patriotic War. Keywords: Great Patriotic War, Soviet Union, victory, creators of victory, ideological struggle, falsification and falsifiers of history

\footnotetext{
1 Путин заявил о «краже у России победы и Берлина»: россиян разозлило притворство. Доступ: https://www.obozrevatel.com/russia/putin-zayavil-o-krazhe-u-rossii-pobedyi-i-berlina-rossiyan-razozlilopritvorstvo.htm (проверено 24.05.2020).
} 